\title{
COMPARISON OF THE GENETIC VARIABILITY OF THREE REGIONS OF CHLOROPLAST DNA AND NUCLEAR DNA IN ISHPINGO (OCOTEA QUIXOS) COMING FROM FIVE PROVINCES OF THE ECUADORIAN AMAZON
}

\author{
SALAZAR, P. ${ }^{1 *}-$ Rivas, P. I. ${ }^{1}-$ MÁTYÁs, B. ${ }^{2}-$ KAROLYS, G. ${ }^{1,3}$ \\ ${ }^{I}$ Faculty of Sciences, Engineering in Biotechnology of Human Resources, Universidad \\ Politécnica Salesiana, Av. 12 de Octubre 2422 and Wilson, Quito, Ecuador \\ (phone: +593-2-396-2900; fax: +593-2-396-2800) \\ ${ }^{2}$ Grupo de Investigación en Ciencias Ambientales (GRICAM), Universidad Politécnica \\ Salesiana, Rumichaca y Morán Valverde s/n, Quito, Ecuador \\ (phone: +593-2-396-2900; fax: +593-2-396-2800) \\ ${ }^{3}$ Grupo de I+D en Ciencias Aplicadas a los Recursos Biológicos (GIDCARB), Universidad \\ Politécnica Salesiana, Av. 12 de Octubre 2422 and Wilson, Quito, Ecuador \\ (phone: +593-2-396-2900; fax: +593-2-396-2800) \\ *Corresponding author \\ email: psalazarc@est.ups.edu.ec; phone: +593-9-271-6930
}

(Received $8^{\text {th }}$ Nov 2018; accepted $5^{\text {th }}$ Mar 2019)

\begin{abstract}
Ocotea quixos (Lam.) Kosterm. (Ishpingo) is a tree that grows in humid tropical forests in South America (310-1200 masl). It is used for food and medicine, since it possesses essential oils with antiplatelet and antithrombotic properties, among others. In Ecuador, the wild populations of Ishpingo have been reduced ecosystem transformation, deforestation and clonal cultivation. This study compared the genetic variability of three regions of chloroplast DNA (i.e., matK, rbcLa and psbA-trnH) and one nuclear region (i.e., ITS) in Ishpingo from 5 provinces of the Ecuadorian Amazon. Based on the obtained alignments, the phylogeny was performed by using the maximum likelihood criterion with a bootstrap of 1000 replicates and with the Jukes-Cantor correction. The genetic variability was determined using the DNA conservation coefficient and the Nei $(\pi)$ nucleotide variability coefficient. The nucleotide variability of matK, rbcLa and psbA-trnH regions was low $(\pi \leq 0.005)$ due to their high conservation degrees. The ITS region presented a superior variability $(\pi=0.11)$ by grouping the samples that were analyzed into two clades. The regions that were analyzed were not useful for the study of genetic variability in Ishpingo. Therefore, it is recommended that new chloroplast and nuclear DNA regions be analyzed to allow studies on the population genetics of this species in Ecuador to be carried out.
\end{abstract}

Keywords: Ocotea, chloroplast, DNA, Amazonia, genetic variability

\section{Introduction}

Ocotea quixos (Lam.) Kosterm. (Ishpingo, Ishpink or Canela Amazónica), is a perennial tree that reaches a height of 2 to $25 \mathrm{~m}$ (Cazorla, 2013; Palacios, 2016). It is distributed in the humid tropical forests of the Amazonian region of Colombia, Ecuador, Peru and Brazil (310-1200 masl) (Cárdenas et al., 2015).

In 2007, Ocotea quixos was banned from commercialization for six months due to the significant reduction from wild populations (Grijalva et al., 2012). In the Ministerial Agreement No. 167, published in the official Register No. 18 on February 8, 2007, it was reported that the main causes of the population reduction of Ocotea quixos are the 
expansion of the road network, the transformation of ecosystems, deforestation and the clonal cultivars of the species (Ministerio del Ambiente de Ecuador, 2010).

The lack of genetic studies on the Ocotea quixos populations of Ecuador suggests that the genetic variability of Ishpingo may be declining. The objective of this study is to compare the genetic variability of the three regions of chloroplast DNA (i.e., MatK, rbcLa, psbA-trnH)) and a region of nuclear DNA (i.e., ITS) in Ocotea quixos to establish possible regions for future population genetics studies on Ishpingo.

\section{Materials and methods}

Botanical samples and the 38 foliar tissue samples of Ishpingo (Ocotea quixos) species were collected. The samples were obtained from 11 locations in 5 provinces of the Ecuadorian Amazon, where Ishpingo is traditionally cultivated. Botanical specimens were morphologically identified with the help the herbarium of Pontificia Universidad Católica del Ecuador.

Prewashes were performed according to the division protocol of polyphenols and polysaccharides as proposed by Porebski et al. (1997). After washing, Doyle and Doyle's simple foliar DNA extraction protocol (1987) was performed. To determine the presence of the DNA, a horizontal electrophoresis was performed in agarose gel at $1 \%$.

The chloroplast DNA regions (i.e., matK, rbcLa, psbA-trnH) and the nuclear ITS region, defined for the Barcode system, were amplified by specific primers (Table 1).

Table 1. Primers for the amplification of DNA regions

\begin{tabular}{c|c|c}
\hline Primers & Sequence (5'->3') & Reference \\
\hline$m a t K$-1RKIM (F) & ACCCAGTCCATCTGGAAATCTTGGTTC & Lahaye et al. (2008) \\
$m a t K$-3FKIM (R) & CGTACAGTACTTTTGTGTTTACGAG & Lahaye et al. (2008) \\
$r b c L a(\mathrm{~F})$ & ATGTCACCACAAACAGAGACTAAAGC & CBOL Plant Working Group et al. (2009) \\
$r b c L a(\mathrm{R})$ & GTAAAATCAAGTCCACCRCG & Levin et al. (2003) \\
$p s b A(\mathrm{~F})$ & GTTATGCATGAACGTAATGCTC & Kress and Erickson (2007) \\
$t r n H(\mathrm{R})$ & CGCGCATGGTGGATTCACAAATCC & Kress and Erickson (2007) \\
$I T S$ leu1 $(\mathrm{F})$ & GTCCACTGAACCTTATCATTTAG & Bolson et al. (2015) \\
ITS 4 (R) & TCCTCCGCTTATTGATATGC & White et al. (1990) \\
\hline
\end{tabular}

The sequencing and purification of the samples were carried out at the company Macrogen (South Korea) using Sanger's simple sequencing method.

The sequencing analysis was carried out using the MEGA7 program. The MUSCLE algorithm was used to align the sequences, maximum likelihood trees were used for the phylogeny, and the Bootstrap method was performed with 1000 replications. The substitutions that were assessed were nucleotides, and Jukes-Cantor's substitution model (Jukes and Cantor, 1969) was used. The trees were rooted following the criteria of external groups or "outgroups", using the species Ocotea veraguensis and Ocotea porosa. The genetic variability was analyzed with the conservation coefficient, and Nei's variability nucleotide coefficient was determined by the "estimation analysis of 
diversity with the specific data model" (Nei and Li, 1979) and was estimated with Tamura-Nei's model (Tamura et al., 2013).

\section{Results and discussion}

The DNA of 35 samples was obtained (Fig. 1) once the washings were done. The DNA obtained had no signs of degradation and was pollution-free; the band obtained corresponded to the expected size: $>2000 \mathrm{pb}$ with a concentration of approximately 40$100 \mathrm{ng} / \mu \mathrm{L}$.



Figure 1. DNA extraction with previous washings following the protocol of Porebski et al. (1997), and the simple extraction protocol of foliar DNA by Doyle and Doyle (1987), agarose gel at 1\%. (Note: First molecular marker, samples 3204-3215 (+), sample $3213(-)$ )

Out of the 35 sequences of the ITS region obtained, 28 consensus sequences were achieved. The average length of the sequence was $777 \mathrm{pb}$.

The region presented 428 polymorphic areas, a conservation region coefficient of 0.298 and a nucleotide variability coefficient of 0.1137 . ITS presents a low conservation rate due to the great length variability of the sequence, and its incomplete concerted evolution led to the presence of divergent homologous copies within the samples (China Plant BOL Group et al., 2011).

The phylogenetic tree of the ITS region presented two clades; the samples grouped in the first clade were associated with the Ocotea quixos control sequence, and in the second clade, a polyphyletic grouping was observed with a branch support of $100 \%$ (Fig. 2). The presence of two clades may be because ITS has higher discrimination levels and interspecific variability followed by Gao et al. (2010); however, new studies have proven that there are several limitations associated with the ITS region, especially in phylogenetic inference (Gardes and Bruns, 1993), such as in the existence of extensive variations in genome sequences, which are determined by the formation events of duplications, the genomic accommodation of pseudogenes and an incomplete homogenization arrangement). These phenomena create relationships of paralog 
sequences that potentially confuse the accuracy of phylogenetic reconstruction. Homoplasy is higher in ITS than in other DNA regions due to the orthologous/paralogs confusion, compensatory change in bases, problems in alignment due to the accumulation of deletions, and errors in the sequence (Grudinski et al., 2014). Despite being a quasi-universal sequence used in plants for phylogenetic studies, its complex and unpredictable evolutionary behaviour reduces its usefulness in phylogenetic analyses. The use of single-copy nuclear genes is suggested by Alvarez and Wendel (2003).



Figure 2. Maximum likelihood tree ITS region. (Note: A defined clade and a grouped clade can be observed with the O. quixos sequence obtained from GenBank using the MEGA 7 program)

Comparison of nucleotide variability among the regions matK, rbcLa, psbA-trnH and ITS: The psbA-trnH region has a variability coefficient of $\pi=0.0051$ higher than those of the matK and rbcLa regions. This region has mononucleotide repetitions that increase its variability (Kress and Erickson, 2007). Despite this increase, the nucleotide variability coefficient is low <0.1, as mentioned by Jakobsson et al. (2013), and does not provide high nucleotide substitution rates due to its short length in the Ocotea genus, so its nucleotide variability is low (Liu et al., 2012).

The ITS region presented the highest variability coefficient $(\pi=0.1137)$ among the four regions. One of the main reasons for this increase in the genetic variability is due to the homology problem of the sequences that this region has; i.e., the appearance of divergent copies in the samples, which can lead to an increase in the genetic variability, stated by Hollingsworth (2011) and Hollingsworth et al. (2011).

\section{Conclusions}

DNA regions matK, rbcLa and psbA-trnH in Ocotea quixos are preserved (nucleotide variation coefficient $\pi \leq 0.005$ ) for the study of genetic variability in this 
population. The ITS region had highest substitution rates in nucleotides $(\pi=0.1137)$ in the sequences of the Ocotea quixos. This variability is associated with the amount of inscriptions in the DNA sequence that increase the nucleotide variability. The genetic variability coefficient obtained in the DNA regions of Ocotea quixos was low ( $\pi=0$ 0.1137), which suggests that the genetic variability of the species is threatened by deforestation and the cultivation of clones.

Considering our study findings, we highly recommend to continue our research in order to establish possible regions for future population genetics studies on Ishpingo.

\section{REFERENCES}

[1] Alvarez, I. A., Wendel, J. F. (2003): Ribosomal ITS sequences and plant phylogenetic inference. - Molecular Phylogenetics and Evolution 29: 417-434. DOI: 10.1016/S10557903(03)00208-2.

[2] Bolson, M. et al. (2015): ITS and trnH-psbA as efficient DNA barcodes to identify threatened commercial woody angiosperms from southern Brazilian Atlantic rainforests.

- Plos One 10(12): e0143049. DOI: 10.1371/journal.pone.0143049.

[3] Cárdenas, D. et al. (2015): Management Plans for the Conservation of Abarco, Mahogany, Cedar, Paloosa and Canelo de Andaquíes. (Planes de Manejo para la Conservación de Abarco, Caoba, Cedro, Palorosa y Canelo de Andaquíes). - Instituto Amazónico de Investigaciones Científicas, Bogotá. www.sinchi.org.co (accessed: January 28, 2019).

[4] Cazorla, M. (2013): Photoprotective activity of Passion Fruit (Passiflora edulis), Ishpingo (Ocetea quixos) in Phototypes III for Development of a Sunscreen. (Actividad Fotoprotectora de Maracuyá (Passiflora edulis), Ishpingo (Ocetea quixos) en Fototipos III para Elaboración de un Protector Solar). - Escuela Politécnica del Chimborazo, Riobamba. http://dspace.espoch.edu.ec/handle/123456789/2556 (accessed: January 28, 2019).

[5] CBOL Plant Working Group, C. P. W. et al. (2009): A DNA barcode for land plants. Proceedings of the National Academy of Sciences of the United States of America. National Academy of Sciences 106(31): 12794-7. DOI: 10.1073/pnas.0905845106.

[6] China Plant BOL Group, C. P. B. et al. (2011) Comparative analysis of a large dataset indicates that internal transcribed spacer (ITS) should be incorporated into the core barcode for seed plants. - Proceedings of the National Academy of Sciences of the United States of America 108(49): 19641-6. DOI: 10.1073/pnas.1104551108.

[7] Fraga, J. et al. (2004): Comparison between 5 methods for extracting Triatomine DNA: its use in the random amplified polymorphic DNA (RAPD) technique. (Comparación entre 5 métodos para la extracción de ADN de Triatomíneos: su utilización en la técnica de ADN polimórfico amplificado al azar (RAPD)). - Revista Cubana de Medicina Tropical 56: 203-207.

[8] Doyle, J. J, Doyle, J. L. (1987): A rapid DNA isolation procedure for small quantities of fresh leaf tissue. - Phytochem Bull 19: 11-15.

[9] Gao, T. et al. (2010): Evaluating the feasibility of using candidate DNA barcodes in discriminating species of the large Asteraceae family. - BMC Evolutionary Biology 10: 324. DOI: $10.1186 / 1471-2148-10-324$.

[10] Gardes, M., Bruns, T. D. (1993): ITS primers with enhanced specificity for basidiomycetes - application to the identification of mycorrhizae and rusts. - Molecular Ecology 2(2): 113-118. DOI: 10.1111/j.1365-294X.1993.tb00005.x.

[11] Grijalva, J. et al. (2012): Status of Forest Genetic Resources - Country Report. (Ecuador Situación de los Recursos Genéticos Forestales- Informe País-Ecuador). http://www.fao.org/3/i3825e/i3825e20.pdf (accessed: January 28, 2019). 
[12] Grudinski, M. et al. (2014): An evaluation of taxonomic concepts of the widespread plant genus Aglaia and its allies across Wallace's Line (tribe Aglaieae, Meliaceae). Molecular Phylogenetics and Evolution 73: 65-76. DOI: 10.1016/J.YMPEV.2014.01.025.

[13] Hollingsworth, P. M. (2011): Refining the DNA barcode for land plants. - Proceedings of the National Academy of Sciences of the United States of America 108(49): 19451-2. DOI: 10.1073/pnas.1116812108.

[14] Hollingsworth, P. M., Graham, S. W., Little, D. P. (2011): Choosing and using a plant DNA barcode. - PLoS One 6(5): e19254. DOI: 10.1371/journal.pone.0019254.

[15] Jakobsson, M., Edge, M. D., Rosenberg, N. A. (2013): The relationship between F(ST) and the frequency of the most frequent allele. - Genetics 193(2): 515-28. DOI: 10.1534/genetics.112.144758.

[16] Jukes, T. H., Cantor, C. R. (1969): Evolution of Protein Molecules. - In: Munro, H.N. (ed.) Mammalian Protein Metabolism. Academic Press, New York, pp. 21-132. DOI: 10.1016/B978-1-4832-3211-9.50009-7.

[17] Kress, W. J., Erickson, D. L. (2007): A two-locus global DNA barcode for land plants: the coding rbcL gene complements the non-coding trnH-psbA spacer region. - PLoS One 2(6): e508. DOI: 10.1371/journal.pone.0000508.

[18] Lahaye, R. et al. (2008): DNA barcoding the floras of biodiversity hotspots. Proceedings of the National Academy of Sciences of the United States of America 105(8): 2923-8. DOI: 10.1073/pnas.0709936105.

[19] Levin, R. A. et al. (2003): Family-level relationships of Onagraceae based on chloroplast rbc L and ndh F data. - American Journal of Botany 90(1): 107-115. DOI: 10.3732/ajb.90.1.107.

[20] Ministerio del Ambiente de Ecuador (2010): Fourth National Report for the Convention on Biological Diversity (Cuarto Informe Nacional Para El Convenio Sobre La Diversidad Biológica). Ministerio del Ambiente Ecuador, Quito. https://www.cbd.int/doc/world/ec/ec-nr-04-es.pdf (accessed: January 28, 2019).

[21] Nei, M., Li, W. H. (1979): Mathematical model for studying genetic variation in terms of restriction endonucleases. - Proceedings of the National Academy of Sciences of the United States of America 76(10): 5269-73. http://www.ncbi.nlm.nih.gov/pubmed/291943 (accessed: January 28, 2019).

[22] Palacios, W. (2016): Trees of Ecuador: Representative Species. (Árboles del Ecuador: especies representativas). First Ed. - Universidad Técnica del Norte, Ibarra. https://www.researchgate.net/publication/309033659_Arboles_del_Ecuador_especies_rep resentativas.

[23] Porebski, S., Bailey, L. G., Baum, B. R. (1997): Modification of a CTAB DNA extraction protocol for plants containing high polysaccharide and polyphenol components. - Plant Molecular Biology Reporter 15(1): 8-15. DOI: 10.1007/BF02772108.

[24] Tamura, K. et al. (2013): MEGA6: Molecular Evolutionary Genetics Analysis Version 6.0. - Molecular Biology and Evolution 30(12): 2725-2729. DOI: 10.1093/molbev/mst197.

[25] White, T. J. et al. (1990): Amplification and Direct Sequencing of Fungal Ribosomal RNA Genes for Phylogenetics. - In: Innis, M. A. et al. (eds.) Pcr Protocols: a Guide to Methods and Applications. Academic Press, San Diego, pp. 315-322. 


\section{APPENDIX}

Primers for the amplification of DNA regions

\begin{tabular}{|c|c|c|c|c|c|}
\hline$\#$ & $\begin{array}{l}\text { Query } \\
\text { length }\end{array}$ & Description & $\begin{array}{l}\text { Query } \\
\text { cover }\end{array}$ & Identity & Reference \\
\hline $\begin{array}{l}1 \mathrm{D} \\
m a t K\end{array}$ & 895 & $\begin{array}{l}\text { Nectandra sp. } 1 \text { AN410 maturase-like } \\
\text { (matK) gene, partial sequence; choloplast }\end{array}$ & $94 \%$ & $100 \%$ & https://blast.ncbi.nlm.nih.gov/Blast.cgi \\
\hline $\begin{array}{l}2 \mathrm{D} \\
m a t K\end{array}$ & 902 & $\begin{array}{l}\text { Nectandra sp. } 1 \text { AN410 maturase-like } \\
\text { (matK) gene, partial sequence; choloplast }\end{array}$ & $94 \%$ & $99 \%$ & https://blast.ncbi.nlm.nih.gov/Blast.cgi \\
\hline $\begin{array}{l}3 \mathrm{D} \\
\mathrm{matK}\end{array}$ & 856 & $\begin{array}{l}\text { Nectandra sp. } 1 \text { AN410 maturase-like } \\
\text { (matK) gene, partial sequence; choloplast }\end{array}$ & $99 \%$ & $99 \%$ & https://blast.ncbi.nlm.nih.gov/Blast.cgi \\
\hline $\begin{array}{l}\text { 4D } \\
m a t K\end{array}$ & 859 & $\begin{array}{l}\text { Nectandra sp. } 1 \text { AN410 maturase-like } \\
\text { (matK) gene, partial sequence; choloplast }\end{array}$ & $99 \%$ & $99 \%$ & https://blast.ncbi.nlm.nih.gov/Blast.cgi \\
\hline $\begin{array}{l}5 \mathrm{D} \\
\mathrm{matK}\end{array}$ & 859 & $\begin{array}{l}\text { Nectandra } \text { sp. } 1 \text { AN410 maturase-like } \\
\text { (matK) gene, partial sequence; choloplast }\end{array}$ & $99 \%$ & $99 \%$ & https://blast.ncbi.nlm.nih.gov/Blast.cgi \\
\hline $\begin{array}{l}6 \mathrm{D} \\
m a t K\end{array}$ & 845 & $\begin{array}{l}\text { Nectandra } \text { sp. } 1 \text { AN410 maturase-like } \\
\text { (matK) gene, partial sequence; choloplast }\end{array}$ & $100 \%$ & $99 \%$ & https://blast.ncbi.nlm.nih.gov/Blast.cgi \\
\hline $\begin{array}{l}\text { 7D } \\
m a t K\end{array}$ & 851 & $\begin{array}{l}\text { Nectandra sp. } 1 \text { AN410 maturase-like } \\
\text { (matK) gene, partial sequence; choloplast }\end{array}$ & $99 \%$ & $99 \%$ & https://blast.ncbi.nlm.nih.gov/Blast.cgi \\
\hline $\begin{array}{l}8 \mathrm{D} \\
m a t K\end{array}$ & 845 & $\begin{array}{l}\text { Nectandra } \text { sp. } 1 \text { AN410 maturase-like } \\
(m a t K) \text { gene, partial sequence; choloplast }\end{array}$ & $100 \%$ & $99 \%$ & https://blast.ncbi.nlm.nih.gov/Blast.cgi \\
\hline $\begin{array}{l}\text { 9D } \\
m a t K\end{array}$ & 855 & $\begin{array}{l}\text { Nectandra } \text { sp. } 1 \text { AN410 maturase-like } \\
\text { (matK) gene, partial sequence; choloplast }\end{array}$ & $99 \%$ & $99 \%$ & https://blast.ncbi.nlm.nih.gov/Blast.cgi \\
\hline $\begin{array}{l}11 \mathrm{D} \\
\mathrm{matK}\end{array}$ & 857 & $\begin{array}{l}\text { Nectandra } \text { sp. } 1 \text { AN410 maturase-like } \\
(m a t K) \text { gene, partial sequence; choloplast }\end{array}$ & $100 \%$ & $99 \%$ & https://blast.ncbi.nlm.nih.gov/Blast.cgi \\
\hline $\begin{array}{l}12 \mathrm{D} \\
\mathrm{matK}\end{array}$ & 860 & $\begin{array}{l}\text { Nectandra } \text { sp. } 1 \text { AN410 maturase-like } \\
\text { (matK) gene, partial sequence; choloplast }\end{array}$ & $99 \%$ & $99 \%$ & https://blast.ncbi.nlm.nih.gov/Blast.cgi \\
\hline $\begin{array}{l}13 \mathrm{D} \\
\mathrm{matK}\end{array}$ & 847 & $\begin{array}{l}\text { Nectandra } \text { sp. } 1 \text { AN410 maturase-like } \\
\text { (matK) gene, partial sequence; choloplast }\end{array}$ & $96 \%$ & $99 \%$ & https://blast.ncbi.nlm.nih.gov/Blast.cgi \\
\hline $\begin{array}{l}14 \mathrm{D} \\
\mathrm{matK}\end{array}$ & 812 & $\begin{array}{l}\text { Nectandra } \text { sp. } 1 \text { AN410 maturase-like } \\
\text { (matK) gene, partial sequence; choloplast }\end{array}$ & $100 \%$ & $100 \%$ & https://blast.ncbi.nlm.nih.gov/Blast.cgi \\
\hline $\begin{array}{l}17 \mathrm{~A} \\
\operatorname{matK}\end{array}$ & 813 & $\begin{array}{l}\text { Nectandra } \text { sp. } 1 \text { AN410 maturase-like } \\
(m a t K) \text { gene, partial sequence; choloplast }\end{array}$ & $100 \%$ & $100 \%$ & https://blast.ncbi.nlm.nih.gov/Blast.cgi \\
\hline $\begin{array}{l}18 \mathrm{~A} \\
\mathrm{matK}\end{array}$ & 800 & $\begin{array}{l}\text { Nectandra } \text { sp. } 1 \text { AN410 maturase-like } \\
(m a t K) \text { gene, partial sequence; choloplast }\end{array}$ & $100 \%$ & $100 \%$ & https://blast.ncbi.nlm.nih.gov/Blast.cgi \\
\hline $\begin{array}{l}\text { 19A } \\
\text { matK }\end{array}$ & 727 & $\begin{array}{l}\text { Nectandra } \text { sp. } 1 \text { AN410 maturase-like } \\
(m a t K) \text { gene, partial sequence; choloplast }\end{array}$ & $100 \%$ & $100 \%$ & https://blast.ncbi.nlm.nih.gov/Blast.cgi \\
\hline $\begin{array}{l}20 \mathrm{~A} \\
\mathrm{matK}\end{array}$ & 850 & $\begin{array}{l}\text { Nectandra } \text { sp. } 1 \text { AN410 maturase-like } \\
\text { (matK) gene, partial sequence; choloplast }\end{array}$ & $99 \%$ & $99 \%$ & https://blast.ncbi.nlm.nih.gov/Blast.cgi \\
\hline $\begin{array}{l}21 \mathrm{~A} \\
m a t K\end{array}$ & 849 & $\begin{array}{l}\text { Nectandra } \text { sp. } 1 \text { AN410 maturase-like } \\
\text { (matK) gene, partial sequence; choloplast }\end{array}$ & $100 \%$ & $99 \%$ & https://blast.ncbi.nlm.nih.gov/Blast.cgi \\
\hline $\begin{array}{l}22 \mathrm{~A} \\
\mathrm{matK}\end{array}$ & 782 & $\begin{array}{l}\text { Nectandra } \text { sp. } 1 \text { AN410 maturase-like } \\
\text { (matK) gene, partial sequence; choloplast }\end{array}$ & $100 \%$ & $100 \%$ & https://blast.ncbi.nlm.nih.gov/Blast.cgi \\
\hline $\begin{array}{l}23 \mathrm{~A} \\
m a t K\end{array}$ & 811 & $\begin{array}{l}\text { Nectandra } \text { sp. } 1 \text { AN410 maturase-like } \\
\text { (matK) gene, partial sequence; choloplast }\end{array}$ & $100 \%$ & $100 \%$ & https://blast.ncbi.nlm.nih.gov/Blast.cgi \\
\hline $\begin{array}{l}24 \mathrm{~A} \\
\operatorname{mat} K\end{array}$ & 821 & $\begin{array}{l}\text { Nectandra sp. } 1 \text { AN410 maturase-like } \\
(\text { matK) gene, partial sequence; choloplast }\end{array}$ & $99 \%$ & $100 \%$ & https://blast.ncbi.nlm.nih.gov/Blast.cgi \\
\hline
\end{tabular}




\begin{tabular}{|c|c|c|c|c|c|}
\hline $\begin{array}{c}25 \mathrm{~A} \\
m a t K\end{array}$ & 762 & $\begin{array}{l}\text { Nectandra sp. } 1 \text { AN410 maturase-like } \\
(m a t K) \text { gene, partial sequence; choloplast }\end{array}$ & $100 \%$ & $100 \%$ & https://blast.ncbi.nlm.nih.gov/Blast.cgi \\
\hline $\begin{array}{l}26 \mathrm{~A} \\
\operatorname{matK}\end{array}$ & 820 & $\begin{array}{l}\text { Nectandra } \text { sp. } 1 \text { AN410 maturase-like } \\
(\text { matK) gene, partial sequence; choloplast }\end{array}$ & $100 \%$ & $100 \%$ & https://blast.ncbi.nlm.nih.gov/Blast.cgi \\
\hline $\begin{array}{l}27 \mathrm{~A} \\
m a t K\end{array}$ & 778 & $\begin{array}{l}\text { Nectandra sp. } 1 \text { AN410 maturase-like } \\
(m a t K) \text { gene, partial sequence; choloplast }\end{array}$ & $100 \%$ & $100 \%$ & https://blast.ncbi.nlm.nih.gov/Blast.cgi \\
\hline $\begin{array}{l}28 \mathrm{~A} \\
\operatorname{matK}\end{array}$ & 807 & $\begin{array}{l}\text { Nectandra sp. } 1 \text { AN410 maturase-like } \\
(m a t K) \text { gene, partial sequence; choloplast }\end{array}$ & $100 \%$ & $100 \%$ & https://blast.ncbi.nlm.nih.gov/Blast.cgi \\
\hline $\begin{array}{l}29 \mathrm{~A} \\
\mathrm{matK}\end{array}$ & 778 & $\begin{array}{l}\text { Nectandra sp. } 1 \text { AN410 maturase-like } \\
(\text { matK) gene, partial sequence; choloplast }\end{array}$ & $100 \%$ & $100 \%$ & https://blast.ncbi.nlm.nih.gov/Blast.cgi \\
\hline $\begin{array}{l}30 \mathrm{~A} \\
\mathrm{matK}\end{array}$ & 852 & $\begin{array}{l}\text { Nectandra sp. } 1 \text { AN410 maturase-like } \\
(m a t K) \text { gene, partial sequence; choloplast }\end{array}$ & $100 \%$ & $99 \%$ & https://blast.ncbi.nlm.nih.gov/Blast.cgi \\
\hline $\begin{array}{c}31 \mathrm{~A} \\
\mathrm{mat} K\end{array}$ & 797 & $\begin{array}{l}\text { Nectandra } \text { sp. } 1 \text { AN410 maturase-like } \\
(m a t K) \text { gene, partial sequence; choloplast }\end{array}$ & $100 \%$ & $99 \%$ & https://blast.ncbi.nlm.nih.gov/Blast.cgi \\
\hline $\begin{array}{l}32 \mathrm{~A} \\
m a t K\end{array}$ & 793 & $\begin{array}{l}\text { Nectandra sp. } 1 \text { AN410 maturase-like } \\
(m a t K) \text { gene, partial sequence; choloplast }\end{array}$ & $100 \%$ & $99 \%$ & https://blast.ncbi.nlm.nih.gov/Blast.cgi \\
\hline $\begin{array}{l}33 \mathrm{~A} \\
m a t K\end{array}$ & 858 & $\begin{array}{l}\text { Nectandra sp. } 1 \text { AN410 maturase-like } \\
(m a t K) \text { gene, partial sequence; choloplast }\end{array}$ & $99 \%$ & $99 \%$ & https://blast.ncbi.nlm.nih.gov/Blast.cgi \\
\hline $\begin{array}{l}34 \mathrm{~A} \\
\mathrm{matK}\end{array}$ & 809 & $\begin{array}{l}\text { Nectandra sp. } 1 \text { AN410 maturase-like } \\
(m a t K) \text { gene, partial sequence; choloplast }\end{array}$ & $100 \%$ & $99 \%$ & https://blast.ncbi.nlm.nih.gov/Blast.cgi \\
\hline $\begin{array}{l}35 \mathrm{~A} \\
\text { matK }\end{array}$ & 826 & $\begin{array}{l}\text { Nectandra sp. } 1 \text { AN410 maturase-like } \\
\text { (matK) gene, partial sequence; choloplast }\end{array}$ & $100 \%$ & $99 \%$ & $\begin{array}{l}\text { https://blast.ncbi.nlm.nih.gov/Blast.cgi\# } \\
\text { alnHdr_9931066 }\end{array}$ \\
\hline $\begin{array}{l}36 \mathrm{~A} \\
m a t K\end{array}$ & 784 & $\begin{array}{l}\text { Nectandra sp. } 1 \text { AN410 maturase-like } \\
(m a t K) \text { gene, partial sequence; choloplast }\end{array}$ & $100 \%$ & $99 \%$ & https://blast.ncbi.nlm.nih.gov/Blast.cgi \\
\hline $\begin{array}{l}1 \mathrm{~A} \\
r b c L a\end{array}$ & 564 & $\begin{array}{l}\text { Ocotea quixos voucher COAH: } 81062 \\
\text { ribulose-1,5-bisphospahte } \\
\text { carboxylase/oxygenase large subunit } \\
\text { (rbcL) gene, partial cds; choloplast }\end{array}$ & $100 \%$ & $99 \%$ & https://blast.ncbi.nlm.nih.gov/Blast.cgi \\
\hline $\begin{array}{l}2 \mathrm{~A} \\
r b c L a\end{array}$ & 572 & $\begin{array}{l}\text { Ocotea quixos voucher COAH:81062 } \\
\text { ribulose-1,5-bisphospahte } \\
\text { carboxylase/oxygenase large subunit } \\
\text { (rbcL) gene, partial cds; choloplast }\end{array}$ & $99 \%$ & $100 \%$ & https://blast.ncbi.nlm.nih.gov/Blast.cgi \\
\hline $\begin{array}{l}3 \mathrm{~A} \\
r b c L a\end{array}$ & 565 & $\begin{array}{l}\text { Ocotea quixos voucher COAH: } 81083 \\
\text { ribulose-1,5-bisphospahte } \\
\text { carboxylase/oxygenase large subunit } \\
\text { (rbcL) gene, partial cds; choloplast }\end{array}$ & $100 \%$ & $100 \%$ & https://blast.ncbi.nlm.nih.gov/Blast.cgi \\
\hline $\begin{array}{l}\text { 4A } \\
r b c L a\end{array}$ & 565 & $\begin{array}{l}\text { Ocotea quixos voucher COAH:81083 } \\
\text { ribulose-1,5-bisphospahte } \\
\text { carboxylase/oxygenase large subunit } \\
\text { (rbcL) gene, partial cds; choloplast }\end{array}$ & $100 \%$ & $100 \%$ & https://blast.ncbi.nlm.nih.gov/Blast.cgi \\
\hline $\begin{array}{l}5 \mathrm{~A} \\
r b c L a\end{array}$ & 524 & $\begin{array}{l}\text { Ocotea quixos voucher COAH:81083 } \\
\text { ribulose-1,5-bisphospahte } \\
\text { carboxylase/oxygenase large subunit } \\
\text { (rbcL) gene, partial cds; choloplast }\end{array}$ & $100 \%$ & $100 \%$ & https://blast.ncbi.nlm.nih.gov/Blast.cgi \\
\hline $\begin{array}{l}\text { 6A } \\
r b c L a\end{array}$ & 565 & $\begin{array}{l}\text { Ocotea quixos voucher COAH: } 81083 \\
\text { ribulose-1,5-bisphospahte } \\
\text { carboxylase/oxygenase large subunit } \\
\text { (rbcL) gene, partial cds; choloplast }\end{array}$ & $100 \%$ & $100 \%$ & https://blast.ncbi.nlm.nih.gov/Blast.cgi \\
\hline $\begin{array}{l}\text { 7A } \\
r b c L a\end{array}$ & 565 & $\begin{array}{l}\text { Ocotea quixos voucher COAH: } 81083 \\
\text { ribulose-1,5-bisphospahte } \\
\text { carboxylase/oxygenase large subunit } \\
\text { (rbcL) gene, partial cds; choloplast }\end{array}$ & $100 \%$ & $100 \%$ & https://blast.ncbi.nlm.nih.gov/Blast.cgi \\
\hline
\end{tabular}




\begin{tabular}{|c|c|c|c|c|c|}
\hline \multirow{2}{*}{$\begin{array}{c}8 \mathrm{~A} \\
r b c L a\end{array}$} & 540 & $\begin{array}{l}\text { Ocotea quixos voucher COAH: } 81062 \\
\text { ribulose-1,5-bisphospahte } \\
\text { carboxylase/oxygenase large subunit } \\
\text { (rbcL) gene, partial cds; choloplast }\end{array}$ & $100 \%$ & $100 \%$ & https://blast.ncbi.nlm.nih.gov/Blast.cgi \\
\hline & 540 & $\begin{array}{c}\text { Ocotea cymbarum voucher COAH:66878 } \\
\text { ribulose-1,5-bisphosphate } \\
\text { carboxylase/oxygenase large subunit } \\
\text { (rbcL) gene, partial cds; choloplast }\end{array}$ & $100 \%$ & $100 \%$ & https://blast.ncbi.nlm.nih.gov/Blast.cgi \\
\hline \multirow{2}{*}{$\begin{array}{c}9 \mathrm{~A} \\
r b c L a\end{array}$} & 565 & $\begin{array}{c}\text { Ocotea cymbarum voucher COAH:66878 } \\
\text { ribulose-1,5-bisphosphate } \\
\text { carboxylase/oxygenase large subunit } \\
\text { (rbcL) gene, partial cds; choloplast }\end{array}$ & $100 \%$ & $100 \%$ & https://blast.ncbi.nlm.nih.gov/Blast.cgi \\
\hline & 565 & $\begin{array}{l}\text { Ocotea quixos voucher COAH: } 81063 \\
\text { ribulose-1,5-bisphospahte } \\
\text { carboxylase/oxygenase large subunit } \\
\text { (rbcL) gene, partial cds; choloplast }\end{array}$ & $100 \%$ & $100 \%$ & https://blast.ncbi.nlm.nih.gov/Blast.cgi \\
\hline \multirow{2}{*}{$\begin{array}{c}10 \mathrm{~A} \\
r b c L a\end{array}$} & 563 & $\begin{array}{l}\text { Ocotea cymbarum voucher COAH:66878 } \\
\text { ribulose-1,5-bisphosphate } \\
\text { carboxylase/oxygenase large subunit } \\
\text { (rbcL) gene, partial cds; choloplast }\end{array}$ & $100 \%$ & $100 \%$ & https://blast.ncbi.nlm.nih.gov/Blast.cgi \\
\hline & 563 & $\begin{array}{l}\text { Ocotea quixos voucher COAH: } 81062 \\
\text { ribulose-1,5-bisphospahte } \\
\text { carboxylase/oxygenase large subunit } \\
\text { (rbcL) gene, partial cds; choloplast }\end{array}$ & $100 \%$ & $100 \%$ & https://blast.ncbi.nlm.nih.gov/Blast.cgi \\
\hline \multirow{2}{*}{$\begin{array}{c}11 \mathrm{~A} \\
r b c L a\end{array}$} & 521 & $\begin{array}{c}\text { Ocotea cymbarum voucher COAH:66878 } \\
\text { ribulose-1,5-bisphosphate } \\
\text { carboxylase/oxygenase large subunit } \\
\text { (rbcL) gene, partial cds; choloplast }\end{array}$ & $100 \%$ & $100 \%$ & https://blast.ncbi.nlm.nih.gov/Blast.cgi \\
\hline & 521 & $\begin{array}{l}\text { Ocotea quixos voucher COAH:81062 } \\
\text { ribulose-1,5-bisphospahte } \\
\text { carboxylase/oxygenase large subunit } \\
\text { (rbcL) gene, partial cds; choloplast }\end{array}$ & $100 \%$ & $100 \%$ & https://blast.ncbi.nlm.nih.gov/Blast.cgi \\
\hline $\begin{array}{c}13 \mathrm{~A} \\
r b c L a\end{array}$ & 566 & $\begin{array}{l}\text { Ocotea quixos voucher COAH: } 81063 \\
\text { ribulose-1,5-bisphospahte } \\
\text { carboxylase/oxygenase large subunit } \\
\text { (rbcL) gene, partial cds; choloplast }\end{array}$ & $100 \%$ & $100 \%$ & https://blast.ncbi.nlm.nih.gov/Blast.cgi \\
\hline $\begin{array}{l}14 \mathrm{~A} \\
r b c L a\end{array}$ & 567 & $\begin{array}{l}\text { Ocotea quixos voucher COAH:81083 } \\
\text { ribulose-1,5-bisphospahte } \\
\text { carboxylase/oxygenase large subunit } \\
\text { (rbcL) gene, partial cds; choloplast }\end{array}$ & $100 \%$ & $100 \%$ & https://blast.ncbi.nlm.nih.gov/Blast.cgi \\
\hline \multirow{2}{*}{$\begin{array}{c}16 \mathrm{~A} \\
r b c L a\end{array}$} & 389 & $\begin{array}{c}\text { Ocotea cymbarum voucher COAH:66878 } \\
\text { ribulose-1,5-bisphosphate } \\
\text { carboxylase/oxygenase large subunit } \\
\text { (rbcL) gene, partial cds; choloplast }\end{array}$ & $100 \%$ & $100 \%$ & https://blast.ncbi.nlm.nih.gov/Blast.cgi \\
\hline & 389 & $\begin{array}{l}\text { Ocotea quixos voucher COAH: } 81062 \\
\text { ribulose-1,5-bisphospahte } \\
\text { carboxylase/oxygenase large subunit } \\
\text { (rbcL) gene, partial cds; choloplast }\end{array}$ & $100 \%$ & $100 \%$ & https://blast.ncbi.nlm.nih.gov/Blast.cgi \\
\hline \multirow{2}{*}{$\begin{array}{c}\text { 17A } \\
r b c L a\end{array}$} & 563 & $\begin{array}{c}\text { Ocotea cymbarum voucher COAH:66878 } \\
\text { ribulose-1,5-bisphosphate } \\
\text { carboxylase/oxygenase large subunit } \\
\text { (rbcL) gene, partial cds; choloplast }\end{array}$ & $100 \%$ & $100 \%$ & https://blast.ncbi.nlm.nih.gov/Blast.cgi \\
\hline & 563 & $\begin{array}{l}\text { Ocotea quixos voucher COAH:81062 } \\
\text { ribulose-1,5-bisphospahte } \\
\text { carboxylase/oxygenase large subunit } \\
\text { (rbcL) gene, partial cds; choloplast }\end{array}$ & $100 \%$ & $100 \%$ & https://blast.ncbi.nlm.nih.gov/Blast.cgi \\
\hline
\end{tabular}




\begin{tabular}{|c|c|c|c|c|c|}
\hline \multirow{2}{*}{$\begin{array}{l}\text { 18A } \\
r b c L a\end{array}$} & 504 & $\begin{array}{c}\text { Ocotea cymbarum voucher COAH: } 66878 \\
\text { ribulose-1,5-bisphosphate } \\
\text { carboxylase/oxygenase large subunit } \\
\text { (rbcL) gene, partial cds; choloplast }\end{array}$ & $100 \%$ & $100 \%$ & https://blast.ncbi.nlm.nih.gov/Blast.cgi \\
\hline & 504 & $\begin{array}{l}\text { Ocotea quixos voucher COAH: } 81062 \\
\text { ribulose-1,5-bisphospahte } \\
\text { carboxylase/oxygenase large subunit } \\
\text { (rbcL) gene, partial cds; choloplast }\end{array}$ & $100 \%$ & $100 \%$ & https://blast.ncbi.nlm.nih.gov/Blast.cgi \\
\hline \multirow{2}{*}{$\begin{array}{l}19 \mathrm{~A} \\
r b c L a\end{array}$} & 564 & $\begin{array}{c}\text { Ocotea cymbarum voucher COAH:66878 } \\
\text { ribulose-1,5-bisphosphate } \\
\text { carboxylase/oxygenase large subunit } \\
\text { (rbcL) gene, partial cds; choloplast }\end{array}$ & $100 \%$ & $100 \%$ & https://blast.ncbi.nlm.nih.gov/Blast.cgi \\
\hline & 564 & $\begin{array}{l}\text { Ocotea quixos voucher COAH: } 81062 \\
\text { ribulose-1,5-bisphospahte } \\
\text { carboxylase/oxygenase large subunit } \\
\text { (rbcL) gene, partial cds; choloplast }\end{array}$ & $100 \%$ & $100 \%$ & https://blast.ncbi.nlm.nih.gov/Blast.cgi \\
\hline \multirow{2}{*}{$\begin{array}{l}20 \mathrm{~A} \\
r b c L a\end{array}$} & 519 & $\begin{array}{c}\text { Ocotea cymbarum voucher COAH:66878 } \\
\text { ribulose-1,5-bisphosphate } \\
\text { carboxylase/oxygenase large subunit } \\
\text { (rbcL) gene, partial cds; choloplast }\end{array}$ & $99 \%$ & $100 \%$ & https://blast.ncbi.nlm.nih.gov/Blast.cgi \\
\hline & 519 & $\begin{array}{l}\text { Ocotea quixos voucher COAH: } 81062 \\
\text { ribulose-1,5-bisphospahte } \\
\text { carboxylase/oxygenase large subunit } \\
\text { (rbcL) gene, partial cds; choloplast }\end{array}$ & $99 \%$ & $100 \%$ & https://blast.ncbi.nlm.nih.gov/Blast.cgi \\
\hline \multirow{2}{*}{$\begin{array}{l}21 \mathrm{~A} \\
r b c L a\end{array}$} & 510 & $\begin{array}{c}\text { Ocotea cymbarum voucher COAH:66878 } \\
\text { ribulose-1,5-bisphosphate } \\
\text { carboxylase/oxygenase large subunit } \\
\text { (rbcL) gene, partial cds; choloplast }\end{array}$ & $100 \%$ & $100 \%$ & https://blast.ncbi.nlm.nih.gov/Blast.cgi \\
\hline & 510 & $\begin{array}{l}\text { Ocotea quixos voucher COAH:81062 } \\
\text { ribulose-1,5-bisphospahte } \\
\text { carboxylase/oxygenase large subunit } \\
\text { (rbcL) gene, partial cds; choloplast }\end{array}$ & $100 \%$ & $100 \%$ & https://blast.ncbi.nlm.nih.gov/Blast.cgi \\
\hline \multirow{2}{*}{$\begin{array}{l}22 \mathrm{~A} \\
r b c L a\end{array}$} & 556 & $\begin{array}{c}\text { Ocotea cymbarum voucher COAH:66878 } \\
\text { ribulose-1,5-bisphosphate } \\
\text { carboxylase/oxygenase large subunit } \\
\text { (rbcL) gene, partial cds; choloplast }\end{array}$ & $100 \%$ & $100 \%$ & https://blast.ncbi.nlm.nih.gov/Blast.cgi \\
\hline & 556 & $\begin{array}{l}\text { Ocotea quixos voucher COAH:81062 } \\
\text { ribulose-1,5-bisphospahte } \\
\text { carboxylase/oxygenase large subunit } \\
\text { (rbcL) gene, partial cds; choloplast }\end{array}$ & $100 \%$ & $100 \%$ & https://blast.ncbi.nlm.nih.gov/Blast.cgi \\
\hline \multirow{2}{*}{$\begin{array}{l}23 \mathrm{~A} \\
r b c L a\end{array}$} & 564 & $\begin{array}{c}\text { Ocotea cymbarum voucher COAH:66878 } \\
\text { ribulose-1,5-bisphosphate } \\
\text { carboxylase/oxygenase large subunit } \\
\text { (rbcL) gene, partial cds; choloplast }\end{array}$ & $100 \%$ & $100 \%$ & https://blast.ncbi.nlm.nih.gov/Blast.cgi \\
\hline & 564 & $\begin{array}{l}\text { Ocotea quixos voucher COAH: } 81062 \\
\text { ribulose-1,5-bisphospahte } \\
\text { carboxylase/oxygenase large subunit } \\
\text { (rbcL) gene, partial cds; choloplast }\end{array}$ & $100 \%$ & $100 \%$ & https://blast.ncbi.nlm.nih.gov/Blast.cgi \\
\hline \multirow{2}{*}{$\begin{array}{l}24 \mathrm{~A} \\
r b c L a\end{array}$} & 507 & $\begin{array}{c}\text { Ocotea cymbarum voucher COAH:66878 } \\
\text { ribulose-1,5-bisphosphate } \\
\text { carboxylase/oxygenase large subunit } \\
\text { (rbcL) gene, partial cds; choloplast }\end{array}$ & $100 \%$ & $99 \%$ & https://blast.ncbi.nlm.nih.gov/Blast.cgi \\
\hline & 507 & $\begin{array}{l}\text { Ocotea quixos voucher COAH:81062 } \\
\text { ribulose-1,5-bisphospahte } \\
\text { carboxylase/oxygenase large subunit } \\
\text { (rbcL) gene, partial cds; choloplast }\end{array}$ & $100 \%$ & $99 \%$ & https://blast.ncbi.nlm.nih.gov/Blast.cgi \\
\hline
\end{tabular}




\begin{tabular}{|c|c|c|c|c|c|}
\hline \multirow{2}{*}{$\begin{array}{l}25 \mathrm{~A} \\
r b c L a\end{array}$} & 559 & $\begin{array}{c}\text { Ocotea cymbarum voucher COAH: } 66878 \\
\text { ribulose-1,5-bisphosphate } \\
\text { carboxylase/oxygenase large subunit } \\
\text { (rbcL) gene, partial cds; choloplast }\end{array}$ & $100 \%$ & $100 \%$ & https://blast.ncbi.nlm.nih.gov/Blast.cgi \\
\hline & 559 & $\begin{array}{l}\text { Ocotea quixos voucher COAH: } 81062 \\
\text { ribulose-1,5-bisphospahte } \\
\text { carboxylase/oxygenase large subunit } \\
\text { (rbcL) gene, partial cds; choloplast }\end{array}$ & $100 \%$ & $100 \%$ & https://blast.ncbi.nlm.nih.gov/Blast.cgi \\
\hline \multirow{2}{*}{$\begin{array}{l}26 \mathrm{~A} \\
r b c L a\end{array}$} & 562 & $\begin{array}{c}\text { Ocotea cymbarum voucher COAH:66878 } \\
\text { ribulose-1,5-bisphosphate } \\
\text { carboxylase/oxygenase large subunit } \\
\text { (rbcL) gene, partial cds; choloplast }\end{array}$ & $100 \%$ & $99 \%$ & https://blast.ncbi.nlm.nih.gov/Blast.cgi \\
\hline & 562 & $\begin{array}{l}\text { Ocotea quixos voucher COAH: } 81062 \\
\text { ribulose-1,5-bisphospahte } \\
\text { carboxylase/oxygenase large subunit } \\
\text { (rbcL) gene, partial cds; choloplast }\end{array}$ & $100 \%$ & $99 \%$ & https://blast.ncbi.nlm.nih.gov/Blast.cgi \\
\hline \multirow{2}{*}{$\begin{array}{l}27 \mathrm{~A} \\
r b c L a\end{array}$} & 564 & $\begin{array}{c}\text { Ocotea cymbarum voucher COAH:66878 } \\
\text { ribulose-1,5-bisphosphate } \\
\text { carboxylase/oxygenase large subunit } \\
\text { (rbcL) gene, partial cds; choloplast }\end{array}$ & $100 \%$ & $100 \%$ & https://blast.ncbi.nlm.nih.gov/Blast.cgi \\
\hline & 564 & $\begin{array}{l}\text { Ocotea quixos voucher COAH: } 81062 \\
\text { ribulose-1,5-bisphospahte } \\
\text { carboxylase/oxygenase large subunit } \\
\text { (rbcL) gene, partial cds; choloplast }\end{array}$ & $100 \%$ & $100 \%$ & https://blast.ncbi.nlm.nih.gov/Blast.cgi \\
\hline \multirow{2}{*}{$\begin{array}{l}28 \mathrm{~A} \\
r b c L a\end{array}$} & 507 & $\begin{array}{c}\text { Ocotea cymbarum voucher COAH:66878 } \\
\text { ribulose-1,5-bisphosphate } \\
\text { carboxylase/oxygenase large subunit } \\
\text { (rbcL) gene, partial cds; choloplast }\end{array}$ & $98 \%$ & $99 \%$ & https://blast.ncbi.nlm.nih.gov/Blast.cgi \\
\hline & 507 & $\begin{array}{l}\text { Ocotea quixos voucher COAH:81062 } \\
\text { ribulose-1,5-bisphospahte } \\
\text { carboxylase/oxygenase large subunit } \\
\text { (rbcL) gene, partial cds; choloplast }\end{array}$ & $98 \%$ & $99 \%$ & https://blast.ncbi.nlm.nih.gov/Blast.cgi \\
\hline $\begin{array}{l}30 \mathrm{~A} \\
r b c L a\end{array}$ & 567 & $\begin{array}{l}\text { Ocotea quixos voucher COAH: } 81083 \\
\text { ribulose-1,5-bisphospahte } \\
\text { carboxylase/oxygenase large subunit } \\
\text { (rbcL) gene, partial cds; choloplast }\end{array}$ & $100 \%$ & $100 \%$ & https://blast.ncbi.nlm.nih.gov/Blast.cgi \\
\hline \multirow{2}{*}{$\begin{array}{l}31 \mathrm{~A} \\
r b c L a\end{array}$} & 559 & $\begin{array}{c}\text { Ocotea cymbarum voucher COAH:66878 } \\
\text { ribulose-1,5-bisphosphate } \\
\text { carboxylase/oxygenase large subunit } \\
\text { (rbcL) gene, partial cds; choloplast }\end{array}$ & $100 \%$ & $100 \%$ & https://blast.ncbi.nlm.nih.gov/Blast.cgi \\
\hline & 559 & $\begin{array}{l}\text { Ocotea quixos voucher COAH:81062 } \\
\text { ribulose-1,5-bisphospahte } \\
\text { carboxylase/oxygenase large subunit } \\
\text { (rbcL) gene, partial cds; choloplast }\end{array}$ & $100 \%$ & $100 \%$ & https://blast.ncbi.nlm.nih.gov/Blast.cgi \\
\hline \multirow{2}{*}{$\begin{array}{l}33 \mathrm{~A} \\
r b c L a\end{array}$} & 560 & $\begin{array}{c}\text { Ocotea cymbarum voucher COAH:66878 } \\
\text { ribulose-1,5-bisphosphate } \\
\text { carboxylase/oxygenase large subunit } \\
\text { (rbcL) gene, partial cds; choloplast }\end{array}$ & $100 \%$ & $100 \%$ & https://blast.ncbi.nlm.nih.gov/Blast.cgi \\
\hline & 560 & $\begin{array}{l}\text { Ocotea quixos voucher COAH:81062 } \\
\text { ribulose-1,5-bisphospahte } \\
\text { carboxylase/oxygenase large subunit } \\
\text { (rbcL) gene, partial cds; choloplast }\end{array}$ & $100 \%$ & $100 \%$ & https://blast.ncbi.nlm.nih.gov/Blast.cgi \\
\hline $\begin{array}{l}34 \mathrm{~A} \\
r b c L a\end{array}$ & 565 & $\begin{array}{c}\text { Ocotea cymbarum voucher COAH:66878 } \\
\text { ribulose-1,5-bisphosphate } \\
\text { carboxylase/oxygenase large subunit } \\
\text { (rbcL) gene, partial cds; choloplast }\end{array}$ & $100 \%$ & $100 \%$ & https://blast.ncbi.nlm.nih.gov/Blast.cgi \\
\hline
\end{tabular}




\begin{tabular}{|c|c|c|c|c|c|}
\hline & 565 & $\begin{array}{l}\text { Ocotea quixos voucher COAH: } 81063 \\
\text { ribulose-1,5-bisphospahte } \\
\text { carboxylase/oxygenase large subunit } \\
\text { (rbcL) gene, partial cds; choloplast }\end{array}$ & $100 \%$ & $100 \%$ & https://blast.ncbi.nlm.nih.gov/Blast.cgi \\
\hline $\begin{array}{c}1 \mathrm{~B} \\
p s b A-t r n H\end{array}$ & 488 & $\begin{array}{c}\text { Ocotea purpurea voucher Lundell } 21170 \\
\text { PsbA (psbA) gene, partial cds; } p s b A-t r n H \\
\text { intergenic spacer, complete sequence; and } \\
\text { tRNA-His (trnH) gene, partial sequence; } \\
\text { chloroplast }\end{array}$ & $99 \%$ & $97 \%$ & https://blast.ncbi.nlm.nih.gov/Blast.cgi \\
\hline $\begin{array}{c}2 \mathrm{~B} \\
p s b A-\operatorname{trn} H\end{array}$ & 494 & $\begin{array}{l}\text { Ocotea quixos choloplast } p s b A-t r n H \\
\text { intergenic spacer region }\end{array}$ & $96 \%$ & $99 \%$ & https://blast.ncbi.nlm.nih.gov/Blast.cgi \\
\hline $\begin{array}{c}\text { 3B } \\
p s b A-t r n H\end{array}$ & 433 & $\begin{array}{c}\text { Ocotea moschata photosystem II protein } \\
\text { D1 (psbA) gene, partial cds; psbA-trnH } \\
\text { intergenic spacer, complete sequence; and } \\
\text { tRNA-His (trnH) gene, partial sequence; } \\
\text { chloroplast }\end{array}$ & $99 \%$ & $99 \%$ & https://blast.ncbi.nlm.nih.gov/Blast.cgi \\
\hline $\begin{array}{c}\text { 5B } \\
p s b A-t r n H\end{array}$ & 499 & $\begin{array}{c}\text { Ocotea botrantha vouvher s.n. PsbA } \\
\text { (psbA) gene, partial cds; } p s b A-t r n H \\
\text { intergenic spacer, complete sequence; and } \\
\text { tRNA-His (trnH) gene, partial sequence; } \\
\text { chloroplast }\end{array}$ & $97 \%$ & $98 \%$ & https://blast.ncbi.nlm.nih.gov/Blast.cgi \\
\hline $\begin{array}{c}\text { 6B } \\
p s b A-t r n H\end{array}$ & 498 & $\begin{array}{c}\text { Ocotea botrantha voucher Wernisch s.n. } \\
\text { PsbA (psbA) gene, partial cds; } p s b A-t r n H \\
\text { intergenic spacer, complete sequence; and } \\
\text { tRNA-His (trnH) gene, partial sequence; } \\
\text { chloroplast }\end{array}$ & $97 \%$ & $98 \%$ & https://blast.ncbi.nlm.nih.gov/Blast.cgi \\
\hline $\begin{array}{c}\text { 7B } \\
p s b A-t r n H\end{array}$ & 498 & $\begin{array}{l}\text { Ocotea botrantha voucher Wernisch s.n. } \\
\text { PsbA (psbA) gene, partial cds; psbA-trnH } \\
\text { intergenic spacer, complete sequence; and } \\
\text { tRNA-His (trnH) gene, partial sequence; } \\
\text { chloroplast }\end{array}$ & $97 \%$ & $98 \%$ & https://blast.ncbi.nlm.nih.gov/Blast.cgi \\
\hline $\begin{array}{c}8 \mathrm{~B} \\
p s b A-t r n H\end{array}$ & 441 & $\begin{array}{c}\text { Ocotea cuneata voucher } 1079133346 \\
\text { PsbA 9psbA) gene, partial cds; and psbA- } \\
\text { trnH intergenic spacer, complete } \\
\text { sequence; chloroplast }\end{array}$ & $97 \%$ & $99 \%$ & https://blast.ncbi.nlm.nih.gov/Blast.cgi \\
\hline $\begin{array}{c}\text { 9B } \\
p s b A-t r n H\end{array}$ & 489 & $\begin{array}{c}\text { Ocotea purpurea voucher Lundell } 21170 \\
\text { PsbA (psbA) gene, partial cds; } p s b A-t r n H \\
\text { intergenic spacer, complete sequence; and } \\
\text { tRNA-His (trnH) gene, partial sequence; } \\
\text { chloroplast }\end{array}$ & $98 \%$ & $98 \%$ & https://blast.ncbi.nlm.nih.gov/Blast.cgi \\
\hline $\begin{array}{c}10 \mathrm{~B} \\
p s b A-t r n H\end{array}$ & 440 & $\begin{array}{c}\text { Ocotea cuneata voucher } 1079133346 \\
\text { PsbA 9psbA) gene, partial cds; and psbA- } \\
\text { trnH intergenic spacer, complete } \\
\text { sequence; chloroplast }\end{array}$ & $97 \%$ & $99 \%$ & https://blast.ncbi.nlm.nih.gov/Blast.cgi \\
\hline $\begin{array}{c}11 \mathrm{~B} \\
p s b A-t r n H\end{array}$ & 1078 & $\begin{array}{l}\text { Ocotea quixos chloroplast psbA-trnH } \\
\text { intergenic spacer region }\end{array}$ & $44 \%$ & $99 \%$ & https://blast.ncbi.nlm.nih.gov/Blast.cgi \\
\hline $\begin{array}{c}12 \mathrm{~B} \\
p s b A-t r n H\end{array}$ & 573 & Ocotea quixos & $95 \%$ & $99 \%$ & https://blast.ncbi.nlm.nih.gov/Blast.cgi \\
\hline $\begin{array}{c}13 \mathrm{~B} \\
p s b A-t r n H\end{array}$ & 496 & $\begin{array}{c}\text { Ocotea botrantha voucher Wernisch s.n. } \\
\text { PsbA (psbA) gene, partial cds; psbA-trnH } \\
\text { intergenic spacer, complete sequence; and } \\
\text { tRNA-His (trnH) gene, partial sequence; } \\
\text { chloroplast }\end{array}$ & $98 \%$ & $98 \%$ & https://blast.ncbi.nlm.nih.gov/Blast.cgi \\
\hline $\begin{array}{c}14 \mathrm{~B} \\
p s b A-t r n H\end{array}$ & 495 & $\begin{array}{c}\text { Ocotea purpurea voucher Lundell } 21170 \\
\text { PsbA (psbA) gene, partial cds; psbA-trnH } \\
\text { intergenic spacer, complete sequence; and } \\
\text { tRNA-His (trnH) gene, partial sequence; } \\
\text { chloroplast }\end{array}$ & $97 \%$ & $98 \%$ & https://blast.ncbi.nlm.nih.gov/Blast.cgi \\
\hline
\end{tabular}




\begin{tabular}{|c|c|c|c|c|c|}
\hline $\begin{array}{c}16 \mathrm{~A} \\
p s b A-t r n H\end{array}$ & 506 & $\begin{array}{l}\text { Ocotea quixos chloroplast } p s b A-t r n H \\
\text { intergenic spacer region }\end{array}$ & $95 \%$ & $98 \%$ & https://blast.ncbi.nlm.nih.gov/Blast.cgi \\
\hline $\begin{array}{c}17 \mathrm{~A} \\
p s b A-t r n H\end{array}$ & 500 & $\begin{array}{c}\text { Ocotea purpurea voucher Lundell } 21170 \\
\text { PsbA (psbA) gene, partial cds; } p s b A-t r n H \\
\text { intergenic spacer, complete sequence; and } \\
\text { tRNA-His (trnH) gene, partial sequence; } \\
\text { chloroplast }\end{array}$ & $97 \%$ & $97 \%$ & https://blast.ncbi.nlm.nih.gov/Blast.cgi \\
\hline $\begin{array}{c}18 \mathrm{~A} \\
p s b A-t r n H\end{array}$ & 504 & $\begin{array}{l}\text { Ocotea botrantha voucher Wernisch s.n. } \\
\text { PsbA (psbA) gene, partial cds; } p s b A-t r n H \\
\text { intergenic spacer, complete sequence; and } \\
\text { tRNA-His (trnH) gene, partial sequence; } \\
\text { chloroplast }\end{array}$ & $96 \%$ & $98 \%$ & https://blast.ncbi.nlm.nih.gov/Blast.cgi \\
\hline $\begin{array}{c}19 \mathrm{~A} \\
p s b A-t r n H\end{array}$ & 497 & $\begin{array}{l}\text { Ocotea quixos chloroplast } p s b A-t r n H \\
\text { intergenic spacer region }\end{array}$ & $95 \%$ & $99 \%$ & https://blast.ncbi.nlm.nih.gov/Blast.cgi \\
\hline $\begin{array}{c}20 \mathrm{~A} \\
p s b A-\operatorname{trn} H\end{array}$ & 494 & $\begin{array}{c}\text { Ocotea purpurea voucher Lundell } 21170 \\
\text { PsbA (psbA) gene, partial cds; psbA-trnH } \\
\text { intergenic spacer, complete sequence; and } \\
\text { tRNA-His (trnH) gene, partial sequence; } \\
\text { chloroplast }\end{array}$ & $98 \%$ & $98 \%$ & https://blast.ncbi.nlm.nih.gov/Blast.cgi \\
\hline $\begin{array}{c}21 \mathrm{~A} \\
p s b A-t r n H\end{array}$ & 492 & $\begin{array}{c}\text { Ocotea purpurea voucher Lundell } 21170 \\
\text { PsbA (psbA) gene, partial cds; psbA-trnH } \\
\text { intergenic spacer, complete sequence; and } \\
\text { tRNA-His (trnH) gene, partial sequence; } \\
\text { chloroplast }\end{array}$ & $98 \%$ & $98 \%$ & https://blast.ncbi.nlm.nih.gov/Blast.cgi \\
\hline $\begin{array}{c}22 \mathrm{~A} \\
p s b A-t r n H\end{array}$ & 497 & $\begin{array}{l}\text { Ocotea quixos chloroplast } p s b A-t r n H \\
\text { intergenic spacer region }\end{array}$ & $95 \%$ & $98 \%$ & https://blast.ncbi.nlm.nih.gov/Blast.cgi \\
\hline $\begin{array}{c}23 \mathrm{~A} \\
p s b A-t r n H\end{array}$ & 505 & $\begin{array}{l}\text { Ocotea quixos chloroplast } p s b A \text {-trnH } \\
\text { intergenic spacer region }\end{array}$ & $95 \%$ & $99 \%$ & https://blast.ncbi.nlm.nih.gov/Blast.cgi \\
\hline $\begin{array}{c}24 \mathrm{~A} \\
p s b A-t r n H\end{array}$ & 501 & $\begin{array}{l}\text { Ocotea quixos chloroplast psbA-trnH } \\
\text { intergenic spacer region }\end{array}$ & $95 \%$ & $99 \%$ & https://blast.ncbi.nlm.nih.gov/Blast.cgi \\
\hline $\begin{array}{c}25 \mathrm{~A} \\
p s b A-t r n H\end{array}$ & 467 & $\begin{array}{c}\text { Lindera benzoin voucher SERC- } \\
1076419278 \text { trnH-psbA intergenic spacer, } \\
\text { partial sequence; choroplast }\end{array}$ & $96 \%$ & $95 \%$ & https://blast.ncbi.nlm.nih.gov/Blast.cgi \\
\hline $\begin{array}{c}26 \mathrm{~A} \\
p s b A-t r n H\end{array}$ & 505 & $\begin{array}{l}\text { Ocotea quixos chloroplast } p s b A-t r n H \\
\text { intergenic spacer region }\end{array}$ & $95 \%$ & $99 \%$ & https://blast.ncbi.nlm.nih.gov/Blast.cgi \\
\hline $\begin{array}{c}27 \mathrm{~A} \\
p s b A-t r n H\end{array}$ & 504 & $\begin{array}{l}\text { Ocotea quixos chloroplast psbA-trnH } \\
\text { intergenic spacer region }\end{array}$ & $95 \%$ & $99 \%$ & https://blast.ncbi.nlm.nih.gov/Blast.cgi \\
\hline $\begin{array}{c}28 \mathrm{~A} \\
p s b A-t r n H\end{array}$ & 488 & $\begin{array}{l}\text { Ocotea quixos chloroplast } p s b A \text {-trnH } \\
\text { intergenic spacer region }\end{array}$ & $97 \%$ & $99 \%$ & https://blast.ncbi.nlm.nih.gov/Blast.cgi \\
\hline $\begin{array}{c}29 \mathrm{~A} \\
p s b A-t r n H\end{array}$ & 496 & $\begin{array}{l}\text { Ocotea quixos chloroplast } p s b A-t r n H \\
\text { intergenic spacer region }\end{array}$ & $95 \%$ & $99 \%$ & https://blast.ncbi.nlm.nih.gov/Blast.cgi \\
\hline $\begin{array}{c}30 \mathrm{~A} \\
p s b A-t r n H\end{array}$ & 505 & $\begin{array}{l}\text { Ocotea quixos chloroplast } p s b A-t r n H \\
\text { intergenic spacer region }\end{array}$ & $95 \%$ & $99 \%$ & https://blast.ncbi.nlm.nih.gov/Blast.cgi \\
\hline $\begin{array}{c}31 \mathrm{~A} \\
p s b A-\operatorname{trn} H\end{array}$ & 422 & $\begin{array}{l}\text { Ocotea quixos chloroplast } p s b A \text {-trnH } \\
\text { intergenic spacer region }\end{array}$ & $98 \%$ & $99 \%$ & https://blast.ncbi.nlm.nih.gov/Blast.cgi \\
\hline $\begin{array}{c}32 \mathrm{~A} \\
p s b A-t r n H\end{array}$ & 401 & $\begin{array}{c}\text { Ocotea cuneata voucher } 1079133346 \\
\text { PsbA (psbA) gene, partial cds; and psbA- } \\
\text { trnH intergenic spacer, complete } \\
\text { sequence; chloroplast }\end{array}$ & $98 \%$ & $99 \%$ & https://blast.ncbi.nlm.nih.gov/Blast.cgi \\
\hline $\begin{array}{c}33 \mathrm{~A} \\
p s b A-t r n H\end{array}$ & 474 & $\begin{array}{c}\text { Ocotea purpurea voucher Lundell } 21170 \\
\text { PsbA (psbA) gene, partial cds; psbA-trnH } \\
\text { intergenic spacer, complete sequence; and } \\
\text { tRNA-His (trnH) gene, partial sequence; } \\
\text { chloroplast }\end{array}$ & $100 \%$ & $97 \%$ & https://blast.ncbi.nlm.nih.gov/Blast.cgi \\
\hline
\end{tabular}




\begin{tabular}{|c|c|c|c|c|c|}
\hline $\begin{array}{c}34 \mathrm{~A} \\
p s b A-t r n H\end{array}$ & 402 & $\begin{array}{c}\text { Lauraceae sp. MAG2009 voucher NL } \\
110192 \text { PsbA (psbA) gene, partial cds; } \\
\text { and psbA-trnHintergenic spacer, partial } \\
\text { sequence choroplast }\end{array}$ & $99 \%$ & $99 \%$ & https://blast.ncbi.nlm.nih.gov/Blast.cgi \\
\hline $\begin{array}{c}35 \mathrm{~A} \\
p s b A-t r n H\end{array}$ & 330 & $\begin{array}{l}\text { Ocotea cuneata voucher } 1079133346 \\
\text { PsbA (psbA) gene, partial cds; and psbA- } \\
\text { trnH intergenic spacer, complete } \\
\text { sequence; chloroplast }\end{array}$ & $97 \%$ & $99 \%$ & https://blast.ncbi.nlm.nih.gov/Blast.cgi \\
\hline $\begin{array}{c}\text { 36A } \\
p s b A-t r n H\end{array}$ & 445 & $\begin{array}{l}\text { Lindera benzoin voucher SERC- } \\
1076419278 \text { trnH-psbA intergenic spacer, } \\
\text { partial sequence; choroplast }\end{array}$ & $99 \%$ & $95 \%$ & https://blast.ncbi.nlm.nih.gov/Blast.cgi \\
\hline $\begin{array}{c}1 \mathrm{C} \\
\text { ITS }\end{array}$ & 405 & $\begin{array}{l}\text { Brassica oleraceae var. capitata } 18 \mathrm{~S} \\
\text { ribosomal RNA gene, internal transcribed } \\
\text { spacer } 1,5.8 \text { ribosomal RNA gene, } \\
\text { internal transcribed spacer } 2,26 \mathrm{~S} \\
\text { ribosomal RNA gene, and } 45 \mathrm{~S} \text { rDNA } \\
\text { intergenic spacer, complete sequence }\end{array}$ & $71 \%$ & $96 \%$ & https://blast.ncbi.nlm.nih.gov/Blast.cgi \\
\hline $\begin{array}{l}2 \mathrm{C} \\
\text { ITS }\end{array}$ & 734 & $\begin{array}{l}\text { Brassica oleraceae var. capitata } 18 \mathrm{~S} \\
\text { ribosomal RNA gene, internal transcribed } \\
\text { spacer 1, 5.8 ribosomal RNA gene, } \\
\text { internal transcribed spacer } 2,26 \mathrm{~S} \\
\text { ribosomal RNA gene, and } 45 \mathrm{~S} \text { rDNA } \\
\text { intergenic spacer, complete sequence }\end{array}$ & $99 \%$ & $100 \%$ & https://blast.ncbi.nlm.nih.gov/Blast.cgi \\
\hline $\begin{array}{l}3 \mathrm{C} \\
\text { ITS }\end{array}$ & 495 & $\begin{array}{l}\text { Brassica oleraceae var. capitata } 18 \mathrm{~S} \\
\text { ribosomal RNA gene, internal transcribed } \\
\text { spacer } 1,5.8 \text { ribosomal RNA gene, } \\
\text { internal transcribed spacer } 2,26 \mathrm{~S} \\
\text { ribosomal RNA gene, and } 45 \mathrm{~S} \text { rDNA } \\
\text { intergenic spacer, complete sequence }\end{array}$ & $100 \%$ & $99 \%$ & https://blast.ncbi.nlm.nih.gov/Blast.cgi \\
\hline $\begin{array}{l}4 \mathrm{C} \\
I T S\end{array}$ & 671 & $\begin{array}{l}\text { Brassica oleraceae var. capitata } 18 \mathrm{~S} \\
\text { ribosomal RNA gene, internal transcribed } \\
\text { spacer 1, 5.8 ribosomal RNA gene, } \\
\text { internal transcribed spacer } 2,26 \mathrm{~S} \\
\text { ribosomal RNA gene, and } 45 \mathrm{~S} \text { rDNA } \\
\text { intergenic spacer, complete sequence }\end{array}$ & $100 \%$ & $98 \%$ & https://blast.ncbi.nlm.nih.gov/Blast.cgi \\
\hline $\begin{array}{l}5 \mathrm{C} \\
I T S\end{array}$ & 683 & $\begin{array}{l}\text { Ocotea quixos internal trnascribed spacer } \\
\text { 1, partial sequence; } 5.8 \text { ribosomal RNA } \\
\text { gene, internal transcribed spacer 2, 26S } \\
\text { ribosomal RNA gene, and 26S rDNA } \\
\text { intergenic spacer, partial sequence }\end{array}$ & $90 \%$ & $99 \%$ & https://blast.ncbi.nlm.nih.gov/Blast.cgi \\
\hline $\begin{array}{l}6 \mathrm{C} \\
\text { ITS }\end{array}$ & 460 & $\begin{array}{l}\text { Brassica oleraceae var. capitata } 18 \mathrm{~S} \\
\text { ribosomal RNA gene, internal transcribed } \\
\text { spacer 1, 5.8 ribosomal RNA gene, } \\
\text { internal transcribed spacer } 2,26 \mathrm{~S} \\
\text { ribosomal RNA gene, and } 45 \mathrm{~S} \text { rDNA } \\
\text { intergenic spacer, complete sequence }\end{array}$ & $100 \%$ & $99 \%$ & https://blast.ncbi.nlm.nih.gov/Blast.cg \\
\hline $\begin{array}{l}9 \mathrm{C} \\
\text { ITS }\end{array}$ & 507 & $\begin{array}{l}\text { Brassica oleraceae var. capitata } 18 \mathrm{~S} \\
\text { ribosomal RNA gene, internal transcribed } \\
\text { spacer } 1,5.8 \text { ribosomal RNA gene, } \\
\text { internal transcribed spacer } 2,26 \mathrm{~S} \\
\text { ribosomal RNA gene, and } 45 \mathrm{~S} \text { rDNA } \\
\text { intergenic spacer, complete sequence }\end{array}$ & $100 \%$ & $99 \%$ & https://blast.ncbi.nlm.nih.gov/Blast.cgi \\
\hline $\begin{array}{l}10 \mathrm{C} \\
I T S\end{array}$ & 611 & $\begin{array}{l}\text { Brassica oleraceae var. capitata } 18 \mathrm{~S} \\
\text { ribosomal RNA gene, internal transcribed } \\
\text { spacer 1, 5.8 ribosomal RNA gene, } \\
\text { internal transcribed spacer } 2,26 \mathrm{~S} \\
\text { ribosomal RNA gene, and } 45 \mathrm{~S} \text { rDNA } \\
\text { intergenic spacer, complete sequence }\end{array}$ & $61 \%$ & $99 \%$ & https://blast.ncbi.nlm.nih.gov/Blast.cgi \\
\hline
\end{tabular}




\begin{tabular}{|c|c|c|c|c|c|}
\hline $\begin{array}{l}11 \mathrm{C} \\
I T S\end{array}$ & 627 & $\begin{array}{l}\text { Brassica oleraceae var. capitata } 18 \mathrm{~S} \\
\text { ribosomal RNA gene, internal transcribed } \\
\text { spacer } 1,5.8 \text { ribosomal RNA gene, } \\
\text { internal transcribed spacer } 2,26 \mathrm{~S} \\
\text { ribosomal RNA gene, and } 45 \mathrm{~S} \text { rDNA } \\
\text { intergenic spacer, complete sequence }\end{array}$ & $100 \%$ & $100 \%$ & https://blast.ncbi.nlm.nih.gov/Blast.cgi \\
\hline $\begin{array}{r}13 \mathrm{C} \\
I T S\end{array}$ & 694 & $\begin{array}{l}\text { Ocotea quixos internal trnascribed spacer } \\
\text { 1, partial sequence; } 5.8 \text { ribosomal RNA } \\
\text { gene, internal transcribed spacer } 2,26 \mathrm{~S} \\
\text { ribosomal RNA gene, and 26S rDNA } \\
\text { intergenic spacer, partial sequence }\end{array}$ & $89 \%$ & $99 \%$ & https://blast.ncbi.nlm.nih.gov/Blast.cgi \\
\hline $\begin{array}{c}3204 \\
I T S\end{array}$ & 593 & $\begin{array}{l}\text { Brassica oleraceae var. capitata } 18 \mathrm{~S} \\
\text { ribosomal RNA gene, internal transcribed } \\
\text { spacer } 1,5.8 \text { ribosomal RNA gene, } \\
\text { internal transcribed spacer } 2,26 \mathrm{~S} \\
\text { ribosomal RNA gene, and } 45 \mathrm{~S} \text { rDNA } \\
\text { intergenic spacer, complete sequence }\end{array}$ & $100 \%$ & $100 \%$ & https://blast.ncbi.nlm.nih.gov/Blast.cgi \\
\hline $\begin{array}{r}3205 \\
I T S\end{array}$ & 712 & $\begin{array}{c}\text { Brassica oleraceae var. capitata } 18 \mathrm{~S} \\
\text { ribosomal RNA gene, internal transcribed } \\
\text { spacer } 1,5.8 \text { ribosomal RNA gene, } \\
\text { internal transcribed spacer } 2,26 \mathrm{~S} \\
\text { ribosomal RNA gene, and } 45 \mathrm{~S} \text { rDNA } \\
\text { intergenic spacer, complete sequence }\end{array}$ & $100 \%$ & $100 \%$ & https://blast.ncbi.nlm.nih.gov/Blast.cgi \\
\hline $\begin{array}{c}3206 \\
I T S\end{array}$ & 647 & $\begin{array}{l}\text { Ocotea quixos internal trnascribed spacer } \\
\text { 1, partial sequence; } 5.8 \text { ribosomal RNA } \\
\text { gene, internal transcribed spacer } 2,26 \mathrm{~S} \\
\text { ribosomal RNA gene, and } 26 \mathrm{~S} \text { rDNA } \\
\text { intergenic spacer, partial sequence }\end{array}$ & $94 \%$ & $99 \%$ & https://blast.ncbi.nlm.nih.gov/Blast.cgi \\
\hline $\begin{array}{r}3207 \\
I T S\end{array}$ & 559 & $\begin{array}{c}\text { Brassica oleraceae var. capitata } 18 \mathrm{~S} \\
\text { ribosomal RNA gene, internal transcribed } \\
\text { spacer } 1,5.8 \text { ribosomal RNA gene, } \\
\text { internal transcribed spacer } 2,26 \mathrm{~S} \\
\text { ribosomal RNA gene, and } 45 \mathrm{~S} \text { rDNA } \\
\text { intergenic spacer, complete sequence }\end{array}$ & $100 \%$ & $99 \%$ & https://blast.ncbi.nlm.nih.gov/Blast.cgi \\
\hline $\begin{array}{r}3209 \\
I T S\end{array}$ & 709 & $\begin{array}{c}\text { Brassica oleraceae var. capitata } 18 \mathrm{~S} \\
\text { ribosomal RNA gene, internal transcribed } \\
\text { spacer } 1,5.8 \text { ribosomal RNA gene, } \\
\text { internal transcribed spacer } 2,26 \mathrm{~S} \\
\text { ribosomal RNA gene, and } 45 \mathrm{~S} \text { rDNA } \\
\text { intergenic spacer, complete sequence }\end{array}$ & $100 \%$ & $100 \%$ & https://blast.ncbi.nlm.nih.gov/Blast.cgi \\
\hline $\begin{array}{r}3211 \\
I T S\end{array}$ & 620 & $\begin{array}{c}\text { Brassica oleraceae var. capitata } 18 \mathrm{~S} \\
\text { ribosomal RNA gene, internal transcribed } \\
\text { spacer 1, } 5.8 \text { ribosomal RNA gene, } \\
\text { internal transcribed spacer } 2,26 \mathrm{~S} \\
\text { ribosomal RNA gene, and } 45 \mathrm{~S} \text { rDNA } \\
\text { intergenic spacer, complete sequence }\end{array}$ & $100 \%$ & $99 \%$ & https://blast.ncbi.nlm.nih.gov/Blast.cgi \\
\hline $\begin{array}{c}3212 \\
I T S\end{array}$ & 513 & $\begin{array}{l}\text { Ocotea quixos internal trnascribed spacer } \\
\text { 1, partial sequence; } 5.8 \text { ribosomal RNA } \\
\text { gene, internal transcribed spacer } 2,26 \mathrm{~S} \\
\text { ribosomal RNA gene, and } 26 \mathrm{~S} \text { rDNA } \\
\text { intergenic spacer, partial sequence }\end{array}$ & $86 \%$ & $94 \%$ & https://blast.ncbi.nlm.nih.gov/Blast.cgi \\
\hline $\begin{array}{c}3213 \\
I T S\end{array}$ & 719 & $\begin{array}{l}\text { Uncultured eukaryote clone CMH360 } \\
18 \mathrm{~S} \text { ribosomal RNA gene, internal } \\
\text { transcribed spacer 1, 5.8 ribosomal RNA } \\
\text { gene, internal transcribed spacer } 2,28 \mathrm{~S} \\
\text { ribosomal RNA gene, and 45S rDNA } \\
\text { intergenic spacer, partial sequence }\end{array}$ & $100 \%$ & $99 \%$ & https://blast.ncbi.nlm.nih.gov/Blast.cgi \\
\hline
\end{tabular}




\begin{tabular}{|c|c|c|c|c|c|}
\hline $\begin{array}{c}3214 \\
\text { ITS }\end{array}$ & 709 & $\begin{array}{l}\text { Brassica oleraceae var. capitata } 18 \mathrm{~S} \\
\text { ribosomal RNA gene, internal transcribed } \\
\text { spacer } 1,5.8 \text { ribosomal RNA gene, } \\
\text { internal transcribed spacer } 2,26 \mathrm{~S} \\
\text { ribosomal RNA gene, and } 45 \mathrm{~S} \text { rDNA } \\
\text { intergenic spacer, complete sequence }\end{array}$ & $100 \%$ & $100 \%$ & https://blast.ncbi.nlm.nih.gov/Blast.cgi \\
\hline $\begin{array}{c}3215 \\
\text { ITS }\end{array}$ & 701 & $\begin{array}{l}\text { Brassica oleraceae var. capitata } 18 \mathrm{~S} \\
\text { ribosomal RNA gene, internal transcribed } \\
\text { spacer 1, 5.8 ribosomal RNA gene, } \\
\text { internal transcribed spacer } 2,26 \mathrm{~S} \\
\text { ribosomal RNA gene, and } 45 \mathrm{~S} \text { rDNA } \\
\text { intergenic spacer, complete sequence }\end{array}$ & $100 \%$ & $100 \%$ & https://blast.ncbi.nlm.nih.gov/Blast.cgi \\
\hline $\begin{array}{c}3216 \\
\text { ITS }\end{array}$ & 591 & $\begin{array}{l}\text { Ocotea quixos internal trnascribed spacer } \\
\text { 1, partial sequence; } 5.8 \text { ribosomal RNA } \\
\text { gene, internal transcribed spacer } 2,26 \mathrm{~S} \\
\text { ribosomal RNA gene, and } 26 \mathrm{~S} \text { rDNA } \\
\text { intergenic spacer, partial sequence }\end{array}$ & $100 \%$ & $99 \%$ & https://blast.ncbi.nlm.nih.gov/Blast.cgi \\
\hline $\begin{array}{r}3217 \\
\text { ITS }\end{array}$ & 678 & $\begin{array}{l}\text { Ocotea quixos internal trnascribed spacer } \\
\text { 1, partial sequence; } 5.8 \text { ribosomal RNA } \\
\text { gene, internal transcribed spacer 2, 26S } \\
\text { ribosomal RNA gene, and 26S rDNA } \\
\text { intergenic spacer, partial sequence }\end{array}$ & $89 \%$ & $99 \%$ & https://blast.ncbi.nlm.nih.gov/Blast.cgi \\
\hline $\begin{array}{c}3219 \\
\text { ITS }\end{array}$ & 512 & $\begin{array}{l}\text { Ocotea quixos internal trnascribed spacer } \\
\text { 1, partial sequence; } 5.8 \text { ribosomal RNA } \\
\text { gene, internal transcribed spacer 2,26S } \\
\text { ribosomal RNA gene, and 26S rDNA } \\
\text { intergenic spacer, partial sequence }\end{array}$ & $95 \%$ & $99 \%$ & https://blast.ncbi.nlm.nih.gov/Blast.cgi \\
\hline $\begin{array}{c}3220 \\
\text { ITS }\end{array}$ & 359 & $\begin{array}{l}\text { Brassica oleraceae var. capitata } 18 \mathrm{~S} \\
\text { ribosomal RNA gene, internal transcribed } \\
\text { spacer 1, 5.8 ribosomal RNA gene, } \\
\text { internal transcribed spacer } 2,26 \mathrm{~S} \\
\text { ribosomal RNA gene, and } 45 \mathrm{~S} \text { rDNA } \\
\text { intergenic spacer, complete sequence }\end{array}$ & $99 \%$ & $100 \%$ & https://blast.ncbi.nlm.nih.gov/Blast.cgi \\
\hline $\begin{array}{c}3221 \\
\text { ITS }\end{array}$ & 668 & $\begin{array}{l}\text { Ocotea quixos internal trnascribed spacer } \\
1 \text {, partial sequence; } 5.8 \text { ribosomal RNA } \\
\text { gene, internal transcribed spacer 2, 26S } \\
\text { ribosomal RNA gene, and 26S rDNA } \\
\text { intergenic spacer, partial sequence }\end{array}$ & $91 \%$ & $99 \%$ & https://blast.ncbi.nlm.nih.gov/Blast.cgi \\
\hline $\begin{array}{c}3223 \\
\text { ITS }\end{array}$ & 641 & $\begin{array}{l}\text { Ocotea quixos internal trnascribed spacer } \\
1, \text { partial sequence; } 5.8 \text { ribosomal RNA } \\
\text { gene, internal transcribed spacer 2, 26S } \\
\text { ribosomal RNA gene, and 26S rDNA } \\
\text { intergenic spacer, partial sequence }\end{array}$ & $95 \%$ & $99 \%$ & https://blast.ncbi.nlm.nih.gov/Blast.cgi \\
\hline $\begin{array}{c}3224 \\
I T S\end{array}$ & 542 & $\begin{array}{l}\text { Tripodanthus belmirensis voucher } \\
\text { Nickrent } 5050 \text { internal transcribed spacer } \\
\text { 1, partial sequence; } 5.8 \text { ribosomal RNA } \\
\text { gene, internal transcribed spacer } 2,26 \mathrm{~S} \\
\text { ribosomal RNA gene, and } 26 \mathrm{~S} \text { rDNA } \\
\text { intergenic spacer, partial sequence }\end{array}$ & $99 \%$ & $92 \%$ & https://blast.ncbi.nlm.nih.gov/Blast.cgi \\
\hline
\end{tabular}

